\title{
Housing Development Role of in Economy of City Manado
}

\author{
Usman Musa Sjahrain \\ State Islamic Institute (IAIN) of Manado, North Sulawesi - Indonesia \\ Street. Dr. S.H. Sarundajang of Region Ringroad I of City Manado, 95128
}

\begin{abstract}
The development of Manado City housing development which is very rapid accompanied by all the activity of the settlement increased caused to population pressure with socio-economic dynamics has increased. Housing development has been developed by the Government and the private party between businessman and developers of Geriya Paniki Indah housing that provides simple houses of type $36 / 105$ up to luxury houses type 120/525 and is built strived according to the needs of the community and can pay attention to the standards of a decent residential environment, City Manado extensive data of area spatial of by $157.26 \mathrm{Km} 2$, total population 431,880 soul and occupation of density reaches 2,740 soul / Km2..Hypothesis Data Analysis Results (1) states that the construction of housing from decent housing plan and infrastruc healthy housing simultaneously a very significant effect on the economy of City Manado at 67.80 percent. Hypothesis Data Analysis Results (2) states that the housing construction of a decent housing plan significant effect on the economy of City Manado by 31.70 percent and of housing development from healthy housing infrastructure significant effect on the economy of City Manado at 18.15 percent. The condition of the economic structure of the City of Manado for gross regional domestic income based on current prices according to the business field of housing construction in 2017 amounted to $2,960,480.84$ million rupiahs and in 2018 an increase of 3,241,214.69 million rupiahs.
\end{abstract}

Keywords:- Housing development ; Economy.

\section{INTRODUCTION}

The right national development is measured from the development of conformity and optimization of the potential of natural resources, human resources and physical (artificial) resources. Development that do not resting on three resources potential will be difficult to say as sustainable development. Ineffective the development can be experienced if aspects of human resources as part of social aspects are not watch out fo. Traditional values, technological capabilities and human resource potential must be in harmony with the pace of development. Therefore, to achieve sustainable development which rests on space it can be used as an umbrella for development and control policies in its implementation.
Law of the Republic of Indonesia number : 1 of 2011 concerning Housing and Settlement Areas, article 35, (1) Development of large-scale housing with balanced occupancy includes simple houses, medium houses and luxury homes. Article 38 (1) Home development includes the construction of a house single, row house , and or a stacking House. (2) Development houses as referred to in paragraph (1). Developed based on typology, ecology, culture, economic dynamics in each region, as well as considering safety and security factors. (3) The construction of houses as referred to in paragraph (1) may be carried out by everyone, the Government and / or regional government. (4) House and housing developments must be carried out in accordance with the regional spatial plan.

The development of Manado City housing development which is very rapid accompanied by all the activity of the settlement increased and the development of housing development caused to population pressure with socio-economic dynamics has increased. The development of Manado City housing development has been developed by the Government and the private sector, several private entrepreneurs housing developers businessman or developer of Geriya Paniki Indah housing that provides simple houses type $36 / 105$ up to luxury houses type 120/525, located in Paniki Village, Mapanget District, City Manado. Development of housing is built strived according to the needs of the community and can pay attention to the standards of a decent residential environment.

Nurhapni, et al, (2008), stated that the increase in total population and economic activities will impact on land needs, especially for housing development. With various specifications, housing is one of the factors that can trigger an increase in run-off. The greater the building area coefficient (KDB), the greater the run-off volume. The large portion of land use for housing has brought the attention of the government to the maximum extent possible to reduce the impact of the increased run off.

Urip, Santoso, (2013), stated that various housing procurement programs have been carried out by the Government and the private sector (real estate). But what was done was not enough, both in terms of quality and quantity. In terms of numbers, it turns out that the Government and the private sector are only able to provide around $10 \%$ of the housing needs, while the rest are built by developers (property) housing sector and the community itself. 
Economic actors as property developers in the housing sector can carry out housing developments that meet building construction standards and meet the needs of consumers or the public. Housing development can be carried out with efforts to realize the construction of habitable housing region and carry that integrated development and planned and quality of construction that meets building construction standards so that it can make an increased contribution to the economy of City Manado, thus the implementation of housing construction from the plan of adequate housing and healthy housing infrastructure in the economy of the City of Manado expected to increase more.

\section{RESEARCH METHODS}

\section{A. Correlational Research}

In this study, the authors determine the type of research used is correlational research based on the characteristics of the problem under study regarding the extent of the influence or correlational relationship between independent variables (Dependent Variable). According Sangadji, et al., (2010), the notion of correlational research is a type of research with the characteristics of a problem in the form of a correlational relationship between two or more variables and aims to determine whether there is association between two or variables and how far the correlation exists between the variables studied. This type of research emphasizes the determination of the level of relationships that can also be used to make predictions". Furthermore the type of research based on the nature and type of data studied is primary data in the form of the opinions of respondents individually or in groups through direct questionnaires, and secondary data in the form of supplementary data that is further processed are presented in the form of tables or diagrams through observation.

\section{B. Research Concepts and Variables}

The concept is number of meanings or characteristics, which are associated with events object, conditions, situations, and behaviors certain, in other words the concept is an abstract opinion that is generalized from certain facts. The concept is a term and definition used to describe in the abstract an event, situation, group or individual that becomes the center of attention of social science and other sciences.

According to Sangadji, et al., (2010), the concept of expressing something abstraction is formed through the generalization of observations to phenomena. The concept an abstraction of reality that is arranged by classifying phenomena such as: objects, events, attributes, or processes that have characteristics. The concept of having an abstract level is progressive depending on whether easy or not the abstracted is phenomenon can be identified. Concept definition as a) an idea or of idea that is relatively perfect and meaningful, b) an understanding of the object, c) a subjective product derived from the way a person makes an understanding of the object or object through his experience (after making a perception of the object or object.
This research variable is an attribute of a someone or object that has a variation between one person with another or one object with another object, and the research variable is an attribute or vthe nature of value of people, objects or activities that have certain variations determined by researchers to studied and then draw conclusions. Sugiyono, (2017), states research variables are attributes or objects that have variations between one person and another or one object with another object variables can provide attributes from scientific fields or certain activities.

According to Agus, Widaryono, (2019), variables in the statistics can be categorized into two types namely quantitative and qualitative. Quantitative variables are variables that are reported in the form of numerical numbers, qualitative variables are variables that are reported not in the form of number not numeric. Quantitative variables can be categorized into two types namely discrete (descrete) and continuous (contious). Discrete quantitative variables are variables that have certain values, continuous quantitative variables are variables that have interval or distance values (range).

\section{Population and Sample}

In this study, the population is a generalization region consisting of objects and the total number of objects studied which includes all the characteristics or properties of the object under study. Whereas the sample is a portion of the members of the population studied. samples taken from the population must be truly representative (representative). According to Sangadji, et al, (2010), population is a generalization region consisting of subjects or objects with certain qualities and characteristics determined by researchers, while the sample is part of the number and characteristics possessed by the population. The population is the overall spatial area data of $157.26 \mathrm{Km} 2$, the population of 431,880 people and the population density reaches 2,740 people / Km2 and a total of 101 housing locations scattered on 11 (Eleven) Districts: Malalayang, Sario, Wanea, Wenang, Tikala, Paal Dua, Mapanget, Singkil, Tuminting, Bunaken and Bunaken Islands (Central Statistics Agency.2019).

Sugiyono, (2017), states that the sample that will be used in research with the probability sampling technique is a sampling technique that provides equal opportunities for each element (member) of the population to be selected as a sample member, with a technique that is simple random sampling. if in the study will conduct multivariate analysis (regression and correlation multiple), the number of sample members is at least 10 times the number of 5 variables (Independent and Dependent). Samples taken from housing located in the Mapanget sub-district area have a spatial area of $47.76 \mathrm{Km} 2$ and a population aged 17 years and over amounted to 40,433 people and residential locations totaling 40 residential locations. For this study, the sample taken from one of the housing locations is Paniki Indah Housing Area in Mapanget Sub-district with a total of 50 respondent souls and 50 housing units. 


\section{Data Collection Technique}

To obtain better research results in the implementation of the data to be collected in the form of primary and secondary data by conducting data collection techniques as follows: Questionnaire is a data collection tool used in this study to obtain primary data. In this study primary data were obtained using a list of questions submitted to respondents filled with answers freely. The question is in accordance with the research variable or object being studied.

According to Sutrisno, Hadi, (2016), a direct questionnaire is if the list of questions is carried out or sent directly to the person or respondent who wants to be asked for his opinion, while the indirect questionnaire method is if the list of questions is carried out or sent to someone who wants requested to tell about someone else ". Questionnaire is a data collection technique that is done by giving a set of questions or written statements to respondents to answer. The questionnaire is also suitable for use if the number of respondents is quite large and spread over a large region and the questionnaire can be a closed or open question or statement.

Observation is a direct observation in the research location to get secondary data, observation is usually interpreted as a systematic observation or phenomena that are investigated and in a broad sense the observation is actually not only limited to observations made either directly or indirectly. According to Sugiyono, (2017), observation as a data collection technique has specific characteristics and is not limited to people, but also other natural objects. Observation is a complex process, composed of various biological and psychological processes. Observation is a data collection technique that is done by obtaining secondary data. used to provide additional and complement images which are further processed are presented in tables or diagrams. For this study secondary data were obtained from the housing developer Geriya Paniki Indah Manado City and geographic information systems (GIS), monographs, statistics from the Manado City Spatial Agency.

\section{E. Data Analysis}

$>$ Hypothesis Data Analysis (1)

To analyze the extent of the role of housing development $(\mathrm{X})$ of the plan of decent housing (X1) and healthy housing infrastructure (X2) simultaneously on the economy (Y) of City Manado . Analysis of Hypothesis data (1) as follows :

\section{- Multiple Linear Regression Analysis}

Multiple linear regression analysis is used to find out how much influence the variables (X) of (X1) and (X2) simultaneously on the variable (Y).

$$
\begin{aligned}
& \text { Multiple linear regression equation (Sugiyono, 2017). } \\
& \hat{Y} 1=a+b 1 X 1+b 2 X 2 \\
& \text { Information } \quad \hat{\mathrm{Y}} 1=\text { Subjects in the dependent variable predicted subjects } \\
& \mathrm{X} 12=\text { Independent variable } \\
& \text { a }=\text { Price } \mathrm{Y} \text { when price } \mathrm{X}=0 \text { (Constant price) } \\
& \mathrm{b} 12=\text { Regression coefficients-coefficients }
\end{aligned}
$$

Statistical F the test means significance of multiple regressions (Yeri, Sutopo, 2017).

$$
\mathrm{F} 1=\frac{J K_{r e g} / k}{J K_{r e s} / d k}
$$

Information $\quad \mathrm{F} 1=$ Test the significance of multiple regression

$$
J K_{\text {reg }}=\text { Number squared }- \text { square of regression }
$$

$J K_{\text {res }}=$ Number squared - square of residue

$\mathrm{dk} \quad=$ Freedom Degrees $(\mathrm{n}-\mathrm{k}-1)$

$\mathrm{k}=$ Number of independent variables $\mathrm{X}$

\section{- Multiple Correlation Analysis}

Multiple correlation analysis is used to measure the degree of influence of variables (X) of (X1) and (X2) simultaneously on the variable $(\mathrm{Y})$.

Coefficient of double determination (Yeri, Sutopo, 2017)

$$
\mathrm{R}^{2} 1=\frac{J K_{r e g}}{\sum Y i^{2}} .
$$

Information $\quad \mathrm{R}^{2} 1=$ Coefficient of multiple determination

$J K_{\text {reg }}=$ Number squared - square of regression

$\Sigma \mathrm{Y}^{2}=$ Number squared - square of tota

Statistical $t$ the test multiple correlation coefficients (Yeri, Sutopo, 2017).

$$
\mathrm{t} 1=\frac{b i}{\text { Sai }}
$$


Information t1 = significance test the multiple correlation coefficient test

$\mathrm{Sa} 1=$ The standard error of coefficient, $\mathrm{Sai}=\mathrm{Sa} 1$, and $\mathrm{Sa} 2$

$\mathrm{b} 1=$ Coefficients - efficiency, $\mathrm{b} 1$ and $\mathrm{b} 2$

Hypothesis Data Analysis (2)

To determine the level of significance of the role of housing construction (X) of the plan for decent housing (X1) and healthy housing infrastructure (X2) separately on the economy (Y) of Manado City. Analysis of Hypothesis data (2) as follows :

- Simple Linear Regression Analysis

Simple linear regression analysis is used to find out how much influence the variables (X) of (X1) and (X2) separately have on the variable $(\mathrm{Y})$.

Simple linear regression equation (Sugiyono, 2017).

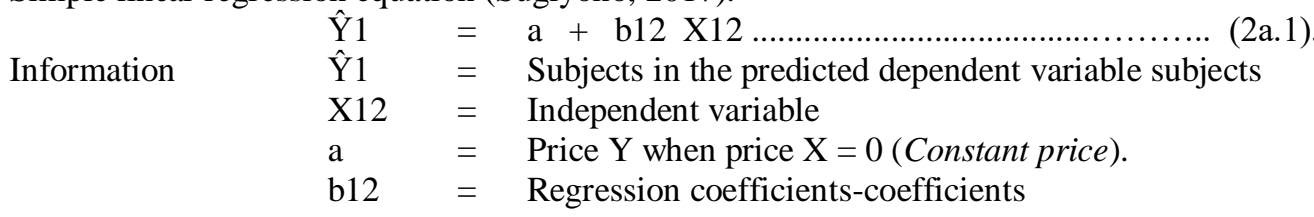

Statistical F the test simple independent regression (Sugiyono, 2017).

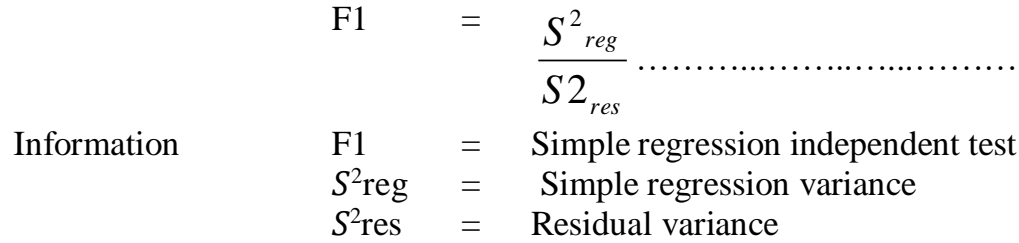

- Partial Correlation Analysis

Partial correlation analysis is used to measure the degree of influence of variables (X) of (X1) and (X2) separately on variables $(\mathrm{Y})$.

Partial correlation coefficient (Supangat, A., 2010).

$$
\text { ry1.2 }=\frac{r y 1 .-r y 2 . . r 1.2 .}{\sqrt{\left(1-r^{2} y 2 .\right)\left(1-r^{2} 1.2 .\right)}}
$$

Information

$$
\begin{array}{lll}
\text { ry1.2 } & =\text { Partial correlation coefficient } \\
\text { ry1 } & =\text { ry } 2=\mathrm{r} 1.2=\text { Correlation coefficients }- \text { coefficients }
\end{array}
$$

St Statistical t the test partial correlation coefficient (Supangat, A., 2010).

$$
\mathrm{t} 1=\frac{r y 1.2 \sqrt{n-2}}{\sqrt{1-r^{2} y 1.2}}
$$

Information $\quad \mathrm{t} 1=$ Test partial correlation coefficient, $\mathrm{ti}=\mathrm{t} 1$ and $\mathrm{t} 2$

$$
\text { ry1.2 = Partial correlation coefficient }
$$

\section{RESEARCH RESULTS AND DISCUSSION}

A. Description of Location of Housing Development

Data area of regional layout of City Manado is $157.26 \mathrm{Km}^{2}$, total population is 431,880 people, occupation density reaches 2,740 people per Km2 and total 101 residential locations are spread across 11 (eleven) Sub districts: Malalayang, Sario, Wanea, Wenang, Tikala, Paal Dua, Mapanget, Singkil, Tuminting, Bunaken and Bunaken Kepulauan (Central Statistics Agency, 2019). 


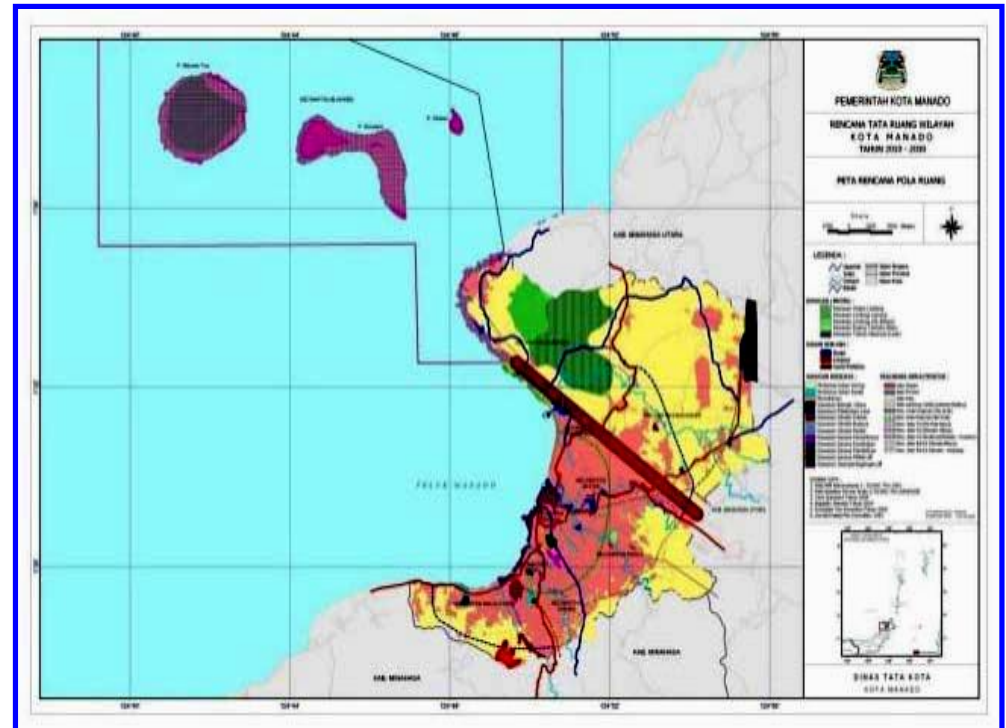

Fig 1:- Map Spatial of City Manado

Source: Statistics Central Board City Manado, 2019

The Manado City housing development plan requires extensive of land and the location must be suitable for residence. The selection of land to be developed must be in a strategic region in accordance with the objectives of housing development. The location of housing development requires a large area of land namely Geriya Paniki Indah Housing Area Mapanget Sub district with a total of 40 housing locations, spatial area of $47.76 \mathrm{Km} 2$. The location of housing construction requires extensive land and the location must be suitable for residence.

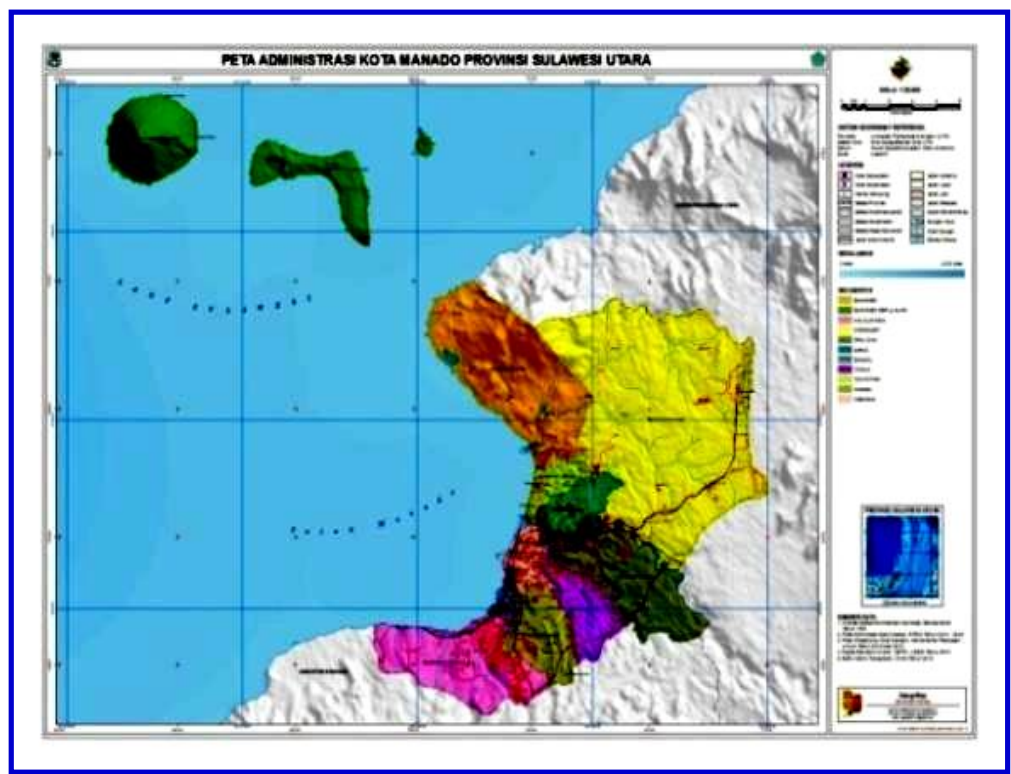

Fig 2:- Map of City Manado Government Region

Source: Statistics Central Board City Manado, 2019

The selection of land to be developed must be in a strategic region in accordance with the objectives of the housing development. Provision of facilities-facilities needed later in implementation is also prepared carefully. And no less important is housing construction activities must be able to provide homes that are habitable for consumers. Seeing thing this, housing development is a potential business for developers to run.
Topography is a study or detailed decomposition of the state of the earth in an area, such as the location of latitude and longitude, slope, altitude, and contour of the soil, climate is the state of the average weather in an area within a period of time relatively long time. Some elements that can be used to determine the climate of an area are air temperature, humidity, solar radiation, rainfall and wind. Air temperature is the degree of hot and cold air in the atmosphere (Badan Pusat Statistik, 1920). 


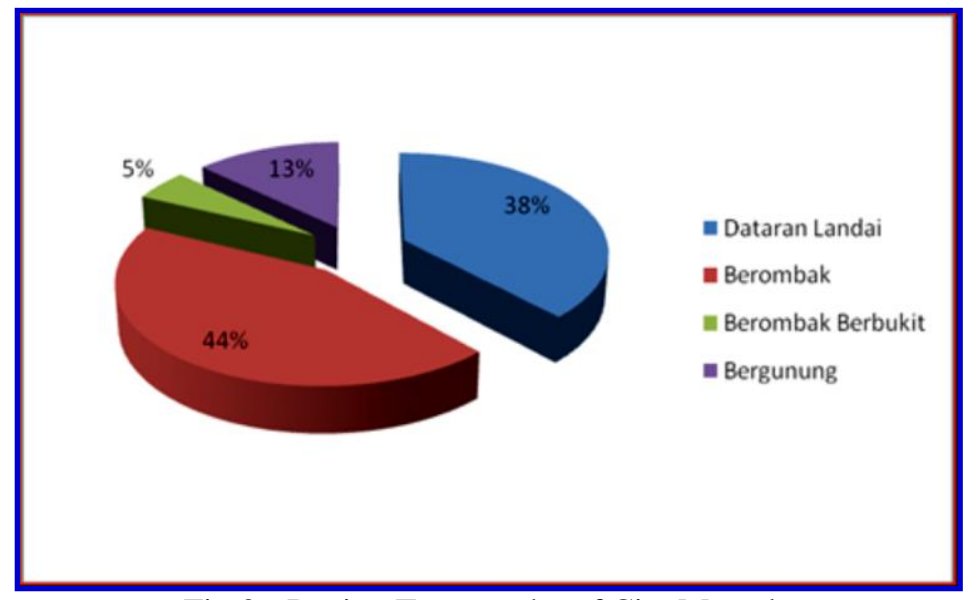

Fig 3:- Region Topography of City Manado

Source: Statistics Central Board City Manado, 2019

Land utilization can guarantee all interests, namely the interests of the government and the community in a fair and integrated way that is meant by integrated is spatial is analyzed and formulated into a single unit of various land use activities, both by the government and the community. Suwitno, Y., Imran, (2013), stated spatial is essentially intended to achieve optimal utilization of resources while avoiding conflicts over resource use, preventing environmental damage and increasing harmony. Within the scope of spatial is land use and allocation become an inseparable part of the spatial concept in development.

According to Amiko, Seng, et al., (2015), region spatial plans, including the activities land use planning, land use management and land use control activities with regard to technological developments. Land use is a form of activity or business utilizing land to meet certain needs. This can open up housing development opportunities in the property business sector by the developer.

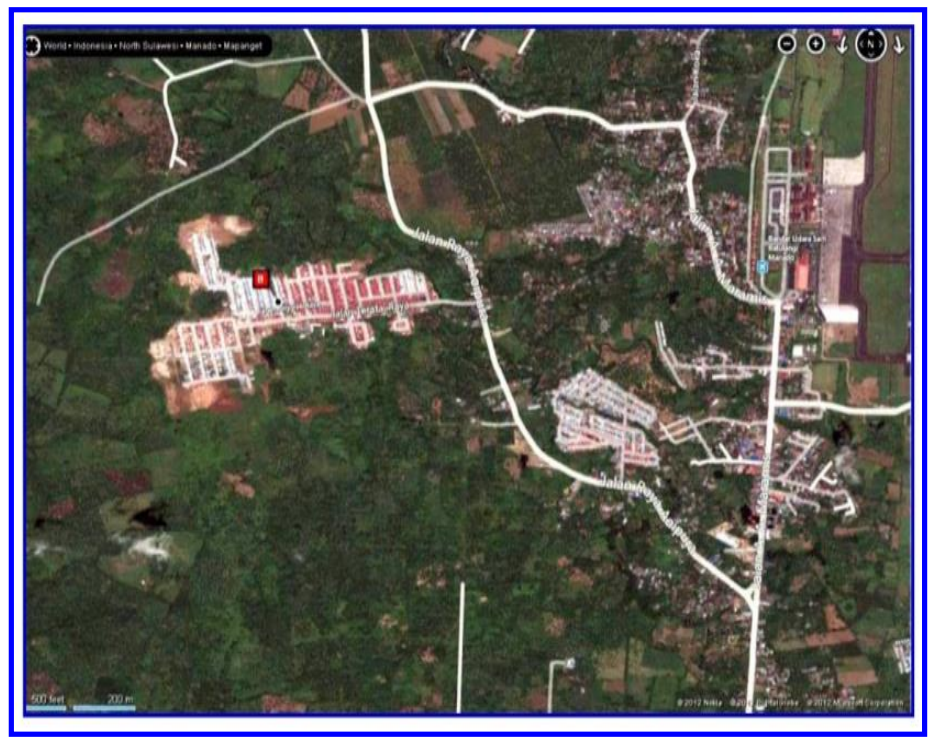

Fig 4:- Housing Location Griya Paniki Indah City of Manado

Source : Housing Develover Geriya Paniki Indah City of Manado, 2019

Regional Regulation of City Manado Number. 01 of 2014 concerning Spatial Planning Article 39 (1) The development of housing allotment areas as referred to in Article 38 letter a, includes: a. very high density housing (KDB greater than $75 \%$ ) includes housing in the Wenang, Sario, Singkil, and Tuminting Sub districts with an area of approximately $266 \mathrm{Ha}$; b. High density housing (KDB 60\% $-75 \%$ ) includes housing in parts of Wanea Sub-district and part of Tikala Sub-district and Paal Dua Sub-district, with an area of approximately $577 \mathrm{Ha}$; c. medium density housing (KDB $45 \%-59 \%$ ) includes housing in parts of
Wanea Subdistrict, part of Tikala Sub district and Paal Dua Subdistrict, and Malalayang Subdistrict, part of Mapanget Sub district with an area of approximately $600 \mathrm{Ha}$; and d. low density housing (KDB 30\% -44\%) includes housing in a part of Mapanget Sub district, Sub district Bunaken and Bunaken Kepulauan Sub district with an area of approximately 667 Ha. (2) Housing development is directed vertically in the form of home flats, apartments, in Sario Sub district, Wanea, Wenang, Singkil, Tuminting and Malalayang Sub dstrict. 


\section{B. Decent Housing Plan}

Housing planning must use an ecological approach, housing is seen as an inseparable part of the ecosystem. All parts of the house, starting from the process of making, using, to dismantling it will greatly affect the balance of nature. According to Santoso, Urip, (2013), Housing is a house whose entire process of development, use and demolition-trying not to disturb the balance of nature, even if possible improve the quality of the environment. That efforts for the comfort and health of occupants must be achieved with a technical approach that does not damage nature even if it is possible to improve the quality of the environment.

According to Ary, D., Putranto, (2013), housing planning is a good and directed environmental management, because the environment of a housing is a very determining factor and its existence should not be ignored. Consideration in environmental factors in the planning of the housing environment is absolutely necessary because in essence the process of forming a housing environment is the accumulation of housing units as forming housing.

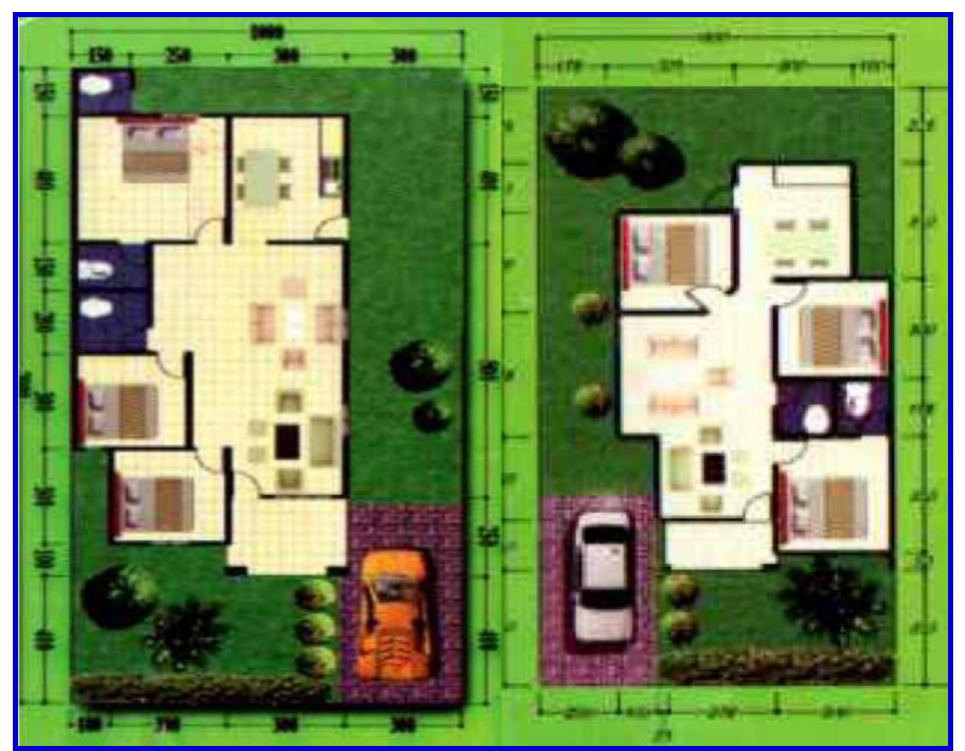

Fig 5:- Floor Plan of Housing Plan of Decent

Source : Housing Develover Geriya Paniki Indah City of Manado, 2019

The house is a building that functions as a residence or occupancy and means of family coaching. Flats are multi-storey buildings built in an environment, divided into functionally structured sections in horizontal and vertical directions and are units each of which can be used separately, especially for residential areas, which is equipped with pthe same parts-parts. A decent house is a house that meets the building safety requirements and the minimum adequacy of the building area and the health of its occupants.

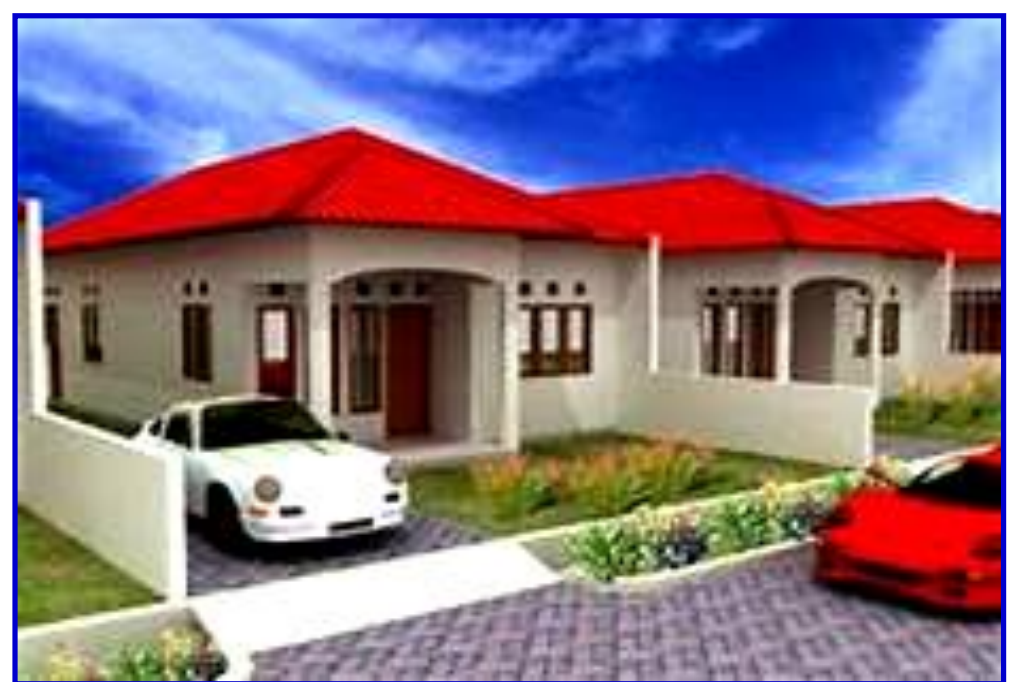

Fig 6:- Front View of Housing Plan of Decent

Source : Housing Develover Geriya Paniki Indah City of Manado, 2019 
Adequacy of livable home lighting of minimum 50\% of the wall facing open space for the living room and a minimum of $10 \%$ of the wall facing open space for sleeping space.The adequacy of the maintenance of a decent house for a minimum of $10 \%$ of the floor area, and the provision of sanitation of at least 1 bathroom and latrine inside or outside the building and is equipped with buildings under septic tank or with communal sanitation, minimum house area of livable between $7.2 \mathrm{~m} 2$ per person to $12 \mathrm{~m} 2$ per person with the main function as a residence consisting of a multipurpose room and bedroom and equipped with a bathroom.

\section{Healthy Housing Infrastructure}

The construction of settlement infrastructure is improve the quality of life and livelihoods, the dignity, the degree and dignity of the residents of a healthy and orderly residential community, to realize a better arranged city area in accordance with its function as stipulated in the relevant urban spatial plan, to encourage more efficient use of land by building home flats, increasing the orderliness of building buildings, facilitating the provision of infrastructure and environmental facilities needed for settlements and reducing the disparity in the welfare of residents from various region in urban areas. The purpose of the development of facilities and infrastructure of understanding above is to improve the quality of human life in society by utilizing existing infrastructure optimally in accordance with its function.

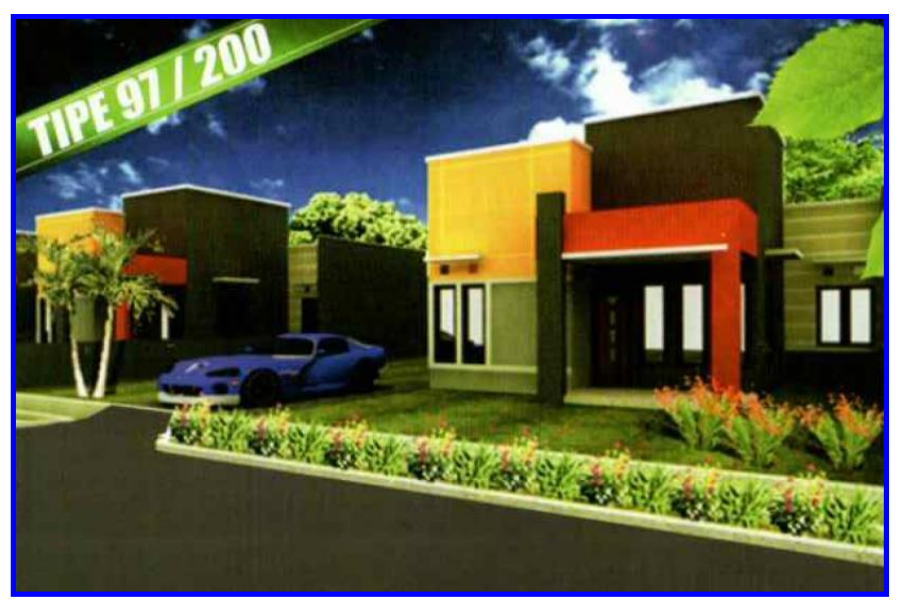

Fig 7:- Front View of Healthy Housing Infrastructure

Source : Housing Develover Geriya Paniki Indah City of Manado, 2019

Asteryna, et al., (2012), stated that the provision of facilities and infrastructure in general is almost always lagging behind the rate of population growth. Dense population in the city will result in increasingly inadequate environmental facilities and infrastructure. Whereas environmental facilities and infrastructure are basic needs and are important factors in increasing social stability, dynamics and community productivity. Asep, Hariyanto, (2006), stated that the construction of housing and settlements that are less integrated, directed, planned, and less attention to the completeness of basic infrastructure and facilities such as clean water, sanitation (latrines), waste management systems, and rainwater drainage systems, will tend experiencing degradation in environmental quality.

\section{Economic Structure Conditions}

The conditions of economic structure in economic analysis need to be distinguished in terms of economic growth and economic development. Both of these concepts in high have a slightly different meaning. The term economic growth explains or measures the achievement of an economic development. And the term economic development is usually associated with economic development in developing countries. Some economists interpret this term as follows: economic development is growth plus change, namely economic development is economic growth followed by changes in the structure and pattern of economic activities Sadono, Sukirno, (2006).

The condition of the economic structure of the City Manado in 2017 regional income or gross regional domestic product (GRDP) used 2 approaches, business field and expenditure. Both present the composition of value-added data broken down by source of economic activity (business field) and by component of its use. (GDP) and (GRDP) from the business side are the sum of all gross value-added components that can be created by economic sectors for their various production activities. While from the expenditure side, it explains about the use of the added value. Regional income or gross regional domestic product (GRDP) is calculated according to two types of measurements, namely on the basis of current prices and on a constant basis. City's Manado gross regional domestic product (PDRB) increased in 2017, as indicated by the nominal value (PDRB) based on current prices of 31.13 trillion rupiahs, Gross regional domestic income based on valid prices according to the business sector in the field of housing construction in 2017 amounted to $2,960,480.84$ million rupiah and in 2018 an increase of 3,241,214.69 million rupiah. 


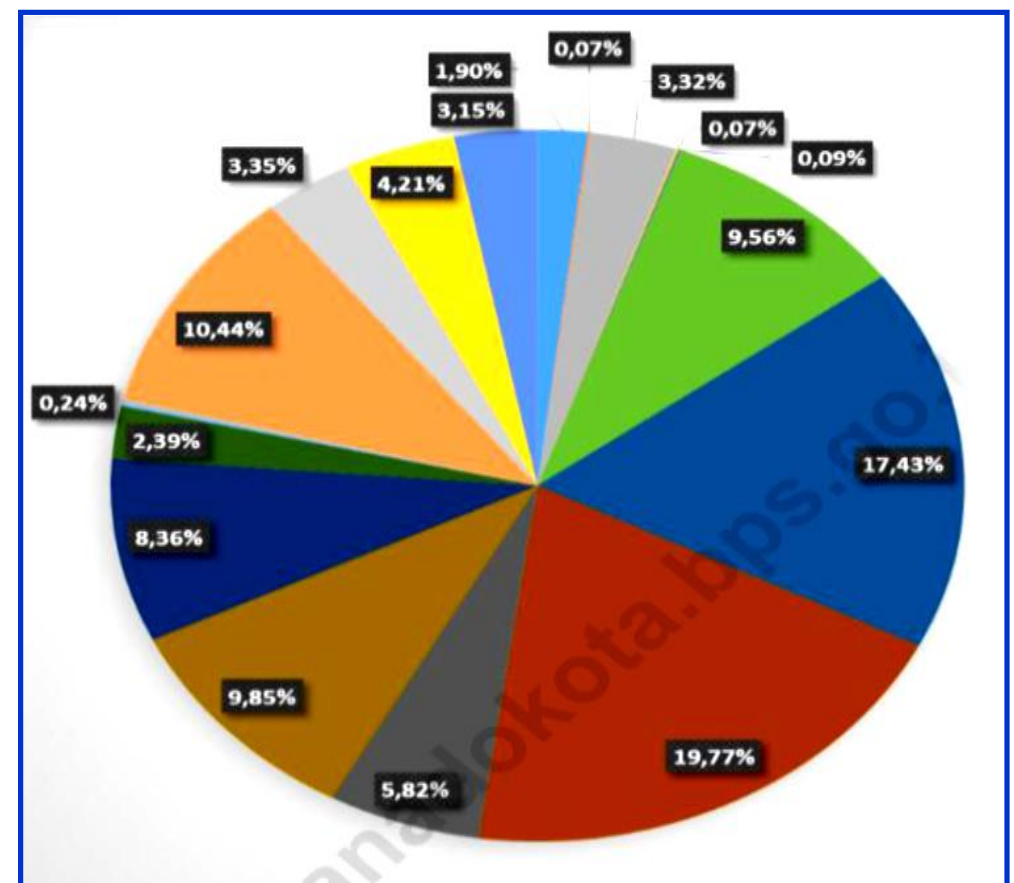

Fig 8:- Economic Structure of City Manado According to Business Field Source: Statistics Central Board City Manado, 2019

Gross domestic income (GDP) according to the business field experienced a change in classification from 9 business fields to 17 business fields. (GDP) according to business sectors broken down according to the total value added of all economic sectors including business fields: agriculture, forestry and fisheries, mining and quarrying, processing industry, electricity and gas procurement, water supply, waste management, waste and recycling Housing construction, Wholesale and retail trade, car and motorcycle repair, transportation and warehousing, provision of accommodation and food and drink, information and communication, financial and insurance services, real estate, company services, government administration, mandatory defense and social security, services education, health services and activities, and other services. So the economic structure of the City of Manado in 2017 Gross domestic income (GDP) according to the business sectors that contributed the highest in the field of transportation and warehousing 19.77 percent, medium real estate 2.39 percent, housing construction 9.56 percent and low service companies 0,24 percent, mining and quarrying 0.07 percent (Central Statistics Agency.2019: 301).

According to Mashudi, et al., (2017). The most ideal economy is the economy achieving full employment in both the short and long term. In other words, every economy always expects that the level of economic growth is always firm so that the full use of labor and other factors of production will always be achieved from one period to another. Revenue is a certain amount of community income that will cause a different pattern of community demand if the income is changed in the style of distribution. The government raises income tax for the rich, lowers the salary of workers, then the pattern of demand for goods will change.

\section{E. Data Analysis Results \\ $>$ Hypothesis Data Analysis (1).}

Hypothesis data analysis according to field observations and preliminary surveys, it is assumed that the role of housing development (X) from the worthy housing plan (X1) and healthy housing infrastructure (X2) simultaneously in the City Manado (Y) economy (Hypothesis 1). The results of the multiple linear regression analysis regarding the relationship between the research variable are stated in the following equation : $\hat{\mathrm{Y}}=0,076+0,612 \mathrm{X} 1+0,440 \mathrm{X} 2$.

The results of the analysis of hypothesis 1 data, with multiple linear regression analysis of table 1 , show the results of the test independent of multiple regression stating that the housing construction (X) of the worthy housing plan (X1) and healthy housing infrastructure (X2) simultaneously have a very significant effect on the economy (Y) City Manado. This conformity is proven by Statistics $\mathrm{F}$ the test independent multiple : F1count = $12.40>\mathrm{F}$ list $=3.35, \mathrm{H} 1$ hypothesis is accepted at the real level $\alpha=0.05$ or $5 \%$ giving the a influential testing very significant. 
ISSN No:-2456-2165

\begin{tabular}{|c|c|c|c|c|}
\hline Nu. & $\begin{array}{c}\text { Analysis } \\
\text { Variables X and Y }\end{array}$ & \multicolumn{3}{|c|}{ Hypothesis Analysis Results 1} \\
\hline 1. & Multiple Linear Regression & Coef. a & Coef. b & F count \\
\hline & $\begin{array}{c}\text { Economy }(\mathrm{Y}) \\
\text { Decent housing plan (X1) } \\
\text { Healt housing infrastructure (X2) }\end{array}$ & 0,076 & $\begin{array}{l}0,612 \\
0,440\end{array}$ & $12,40 *$ \\
\hline 2. & Multiple Correlation : & $\mathrm{R} i$ & $\mathrm{R} i^{2}$ & $t$ count \\
\hline & $\begin{array}{c}\text { Economy (Y) } \\
\text { Decent housing plan (X1) } \\
\text { Healt housing infrastructure (X2) }\end{array}$ & 0,8234 & 0,6780 & $\begin{array}{c}2,36^{*} \\
1,89\end{array}$ \\
\hline
\end{tabular}

Table 1:- Results of Housing Development Analysis (X) And Economy (Y)

Source: processed data, 2019

Note :

1. $\quad$ F list $=0,05(2,27)=3,35$

2. $\mathrm{t}$ list $=(0,975)=2,05$

* = Relationships are Very Significant

The results of the multiple correlation analysis of table 1 , show the coefficient of multiple determination: $\mathrm{R} 12=$ 0.6780 or 67.80 percent, stating that the housing construction (X) from decent housing plan (X1) and healt housing infrastructure (X2) simultaneously have a very significant effect on economy (Y) of City Manado. Conclusion of housing construction the from decent housing plan and healt housing infrastructure simultaneously has a very significant effect on the economy of Manado City at 67.80 percent.

\section{Hypothesis Data Analysis (2).}

To find out the level of significance of the role of housing development (X) of the plan decent housing (X1) and healt housing infrastructure (X2) separately in the City Manado economy (Y). (Hypothesis 2.) For more clarity, below is explained meaningful the role of housing development is outlined below (X). Hypothesis 2 data analysis results, as follows :

\section{- Decent Housing Plan (X1)}

The Role of Housing Development (X) of worthy Housing Plan (X1) in the City Manado economy (Y). The results of simple linear regression analysis regarding the relationship between research variables are expressed in the following equation :

$\hat{\mathrm{Y}}=4,684+0,580 \mathrm{X} 1$

Hypothesis 2 data analysis results, with simple linear regression analysis table 2, shows the results of the independent simple linear regression test states that the housing development $(\mathrm{X})$ of a decent housing plan (X1) has a significant effect on the economy (Y) of City Manado. This conformity is proven by Statistics $F$ the test independent simple : $\mathrm{F} 1$ count $=0.32>\mathrm{F}$ list $=0.24$ hypothesis $\mathrm{H} 1$ accepted at the real level $\alpha=0.05$ or $5 \%$ giving the influential testing significant.

\begin{tabular}{|c|c|c|c|c|}
\hline $\mathrm{Nu}$. & $\begin{array}{c}\text { Analysis } \\
\text { Variables X and Y }\end{array}$ & \multicolumn{3}{|c|}{ Hypothesis Analysis Results 2} \\
\hline 1. & Simple Linear Regression & Coef. a & Coef. b & F count \\
\hline & $\begin{array}{c}\text { Economy (Y) } \\
\text { Decent housing plan (X1) } \\
\text { Healt housing infrastructure (X2) }\end{array}$ & $\begin{array}{l}4,684 \\
4,420\end{array}$ & $\begin{array}{l}0,580 \\
0,520\end{array}$ & $\begin{array}{l}0,32 * \\
0,27 *\end{array}$ \\
\hline 2. & Partial Correlation & ryi & $\mathrm{ryi}^{2}$ & $t$ count \\
\hline & $\begin{array}{c}\text { Economy (Y) } \\
\text { Decent housing plan (X1) } \\
\text { Healt housing infrastructure (X2) }\end{array}$ & $\begin{array}{l}0,5631 \\
0,4260 \\
\end{array}$ & $\begin{array}{l}0,3170 \\
0,1815 \\
\end{array}$ & $\begin{array}{l}4,47 * \\
2,62 * \\
\end{array}$ \\
\hline
\end{tabular}

Table 2:- Results of Housing Development Analysis (X) and Economy (Y)

Source: processed data, 2019

Note :

1. $\quad F$ list $=0,95(1,28)=0,24$

2. $\mathrm{t}$ list $=(0,975)=2,05$

* = Relationships are Very Significant

The results of the partial correlation analysis of table 2. show the coefficient of partial determination: $r 2 y 1.1=$ 0.3170 or 31.70 percent, stating that housing construction (X) of a decent housing plan (X1) separately significant take effect on the City Manado economy (Y). The conclusion of housing development from a worthy housing plan significant effect on the economy of City Manado by 31.70 percent.

According to Dimas, Nugraha, (2011), the implementation of housing and settlements is carried out by prioritizing the achievement of responsive but comprehensive environmental development goals while simultaneously being able to accommodate in a single system with the achievement of social development and 
economic development goals. Hendrawan, (2004) states that the house is a social system rather than a physical system. This is because the house is closely related to humans, which have different social traditions, behaviors and desires that are always dynamic, hence the house is complex in accommodating concepts in man and his life. Some concepts about the house as follows : 1). The house as a manifestation of identity, the house as a symbol and reflection of the personal tastes of the occupants. 2). Home as a place of familiarity of belonging, a sense of togetherness, the warmth of love and a sense of security; 3 ). Home as a place of solitude and solitude; a place to escape from the outside world, from pressure and tension, from the routine world 4). Home as a root and continuity; home is a place back to the roots and foster a sense of continuity in the process string into the future 5). The house as a container for the daily activities 6 ). The house as the center of network social 7). Home as physical structure.

Meeting the needs of settlements is realized through the construction of large-scale residential areas that are planned in a comprehensive and integrated manner with gradual implementation. The development of residential areas is intended to create residential areas that are composed of residential environmental units and integrate in an integrated manner and improve the quality of the existing housing environment in or around it, which is connected by the transportation network in accordance with needs with other areas that provide a variety of services. and job opportunities. Housing and settlement development is carried out based on a comprehensive and integrated urban spatial plan and non-urban spatial plan established by the regional government taking into account various relevant aspects as well as plans, programs and priorities for housing and settlement development.

\section{- Healthy Housing Infrastructure (X2)}

The Role of housing development (X) of healthy housing Infrastructure (X2) in City's Manado economy (Y). The results of simple linear regression analysis regarding the relationship between research variables are expressed in the following equation :

$\hat{\mathrm{Y}}=4,420+0,520 \mathrm{X} 2$

Hypothesis 1 data analysis results, with simple linear regression analysis table 2, shows the results of the independent simple linear regression test states that, housing development (X) from healthy housing infrastructure (X2) has a significant effect on the City Manado economy (Y). This conformity is proven by Statistics $\mathrm{F}$ the test independent simple : F2 count $=2.62>$ $\mathrm{F}$ list $=0.24$ hypothesis $\mathrm{H} 1$ accepted at the real level $\alpha=$ 0.05 or $5 \%$ giving the influential testing significant.

The results of the partial correlation analysis of table 2. show the coefficient of partial determination : $r 2 y 1.2=$ 0.1815 or 18.15 percent, stating housing construction $(\mathrm{X})$ of healthy housing infrastructure (X2) separately significant take effect on the City Manado economy (Y). The conclusion of housing development from healthy housing infrastructure significant effect on the economy of City Manado by 18.15 percent.

Asteryna, et al., (2012) stated that the purpose of the construction of settlement infrastructure is: a). Improving the quality of life and livelihoods, the dignity, status and dignity of the people living in a healthy and orderly settlement. b). Realizing a better arranged city area in accordance with its functions as stipulated in the relevant urban spatial plan. c). Encourage the use of more efficient land with the construction of flats, improve the orderliness of building buildings, facilitate the provision of infrastructure and environmental facilities needed housing and reduce the disparity in the welfare of residents of various regions in urban areas.

According to Soemarno, (2009). Settlement Development, in addition to providing homes for shelter, is to create a healthy living climate, environmentally, economically, socially, and politically, which guarantees the continuation of quality of life for all people, where everyone can live more prosperously, have access on basic infrastructure and settlement services that are appropriate and worthy and are able to maintain the quality of the environment. In order to achieve this goal, it is necessary to: (1) shift the view from the concept of housing development to the concept of settlement development that emphasizes social, functional and ecological integration; (2) creating a conducive climate so that settler communities can be able to build and maintain their dwellings in order to improve their welfare. Some priority activities are: 1). Housing and settlement development, 2). Housing and settlement management.

\section{- $\operatorname{Economy}(Y)$}

Economy is a word that comes from the ancient Greek language "oicos" which means house and "nomos" which means rule. The intention is the rules for carrying out the necessities of life in the household, either at the level of people's households or at the level of the household the state. That is the economy in general while the economy in Islam is often referred to by the name almu 'amalah, which means the rules about the association and human relations regarding the needs of his life. The concept of Economics as a benchmark for the study of economic growth that has already been widely believed and applied, then we must not be left behind and inevitably also must try to learn the nature and the concept of economics. Studies of economics are increasingly being intensively dedicated to knowledge for the general public with the aim of society knowing the economic goals themselves. Thus the increasing public knowledge about economic goals is also expected to increase community welfare.

According to Sadono, Sukirno, (2006). Economic development is defined as a series of efforts in an economy to develop its economic activities so that more infrastructure is available, more and more companies are developing, higher levels of education and technology are increasing. As the implication of this development, it is expected that employment opportunities will increase, 
income levels increase, and the prosperity of the community will become better growth and economic development. Revenue is one of the most important elements of forming an income statement in a company many are confused about the term income. This is because income can be interpreted as income and profit. Revenue is very influential for the whole life of the company, the greater the income obtained, the greater the company's ability to finance all expenses and activities to be carried out by the company. Besides income also affects the company's income and loss presented in the income statement, then, income is the life blood of a company.

According to Soemarso, S. R., (2009). Revenue is the amount charged to customers for goods and services sold. Revenue is the inflows of assets or debt reduction obtained from the delivery of goods or services to customers. Revenue is an increase in company capital due to the sale of company products. 5 Inflows of assets or other increases in assets or the settlement of an entity's obligations (or a combination of both) from the sender of goods, rendering services or other activities that are the main operations or central operations of the company. Furthermore according to Sadono Sukirno (2006: 47) Income is the income of money received and given to economic subjects based on achievements submitted in the form of income from the profession that is done alone or individual business and income from wealth the amount of income depends on the type of work.

Soekartawi, (2012) states that income will affect the amount of goods consumed, that is often found with an increase in income, the goods consumed not only increase, but also the quality of the goods come to the attention. For example, before the increment of rice income which is assumed to be of poor quality, but after the addition of income the consumption of rice becomes better quality. One's income is influenced by several factors, including: 1) The number of production factors that are owned from, this year's savings and inheritance results. 2) The price per unit of each factor of production, this price is determined by the supply and demand in the factor of production market.3) The results of the activities of family members as side jobs.

\section{CONCLUSIONS}

Based on the results and discussion above, the findings are :

$>$ Housing development in the city Manado which tends to prioritize the economic side compared to the ecological, socio-cultural, and long-term perspectives due to stronger economic interests. Housing development can pay attention to the spatial structure and the amount of population growth and well-directed environment. Data area of regional layout of City Manado is $157.26 \mathrm{Km} 2$, total population is 431,880 people, its population occupation density reaches 2,740 people per $\mathrm{Km} 2$.

$>$ Hypothesis Data Analysis Results (1) states that the construction of housing from a decent housing plan and healthy housing infrastructure simultaneously a very significant effect on the economy of City Manado at 67.80 percent. Hypothesis Data Analysis Results (2) states that housing development from a worthy housing plan a significant effect on the economy of Manado City by 31.70 percent and housing development from healthy housing infrastructure a significant effect on the economy of City Manado by 18.15 percent.

$>$ The condition of the economic structure of the City Manado in 2017 regional income or gross regional domestic product (GDP) according to the business field of housing construction Rp. 2,960,480.84 million and in 2018 an increase of Rp. 3,241,214.69 million and gross domestic income (GDP) according to the business sector which contributed the highest in transportation and warehousing 19.77 percent, medium in real estate 2.39 percent, housing construction 9.56 percent and low services companies 0.24 percent, mining and quarrying 0.07 percent.

\section{REFERENCES}

[1]. Agus, Widaryono, (2019). Applied Statistics with Excel \& SPSS. Yogyakarta : UPP STIM YKPN, P.1.

[2]. Amiko, Seng, et al., (2015). Analysis of Changes in Region of Water Absorption Areas in the City of Manado, Journal of Sabua, Manado Regional \& Urban Planning Study Program, Vol. 7, No.1: 423 430, March 2015 ISSN 20r r85-7020.

[3]. Asep, Hariyanto, (2006). Strategy for Handling Kumu Area as an Effort to Create a Healthy Housing and Settlement Environment, Journal, PWK, Regional and Urban Planning Study Program. UNISBA.

[4]. Asteryna, et al., (2012). Implementation of Development of Environmental Infrastructure Facilities as a Form of Community Empowerment Program in Dinoyo Malang District, Public Administration Journal, Department of Public Administration, Faculty of Administrative Sciences, UB Malang, Vol. 1, No. 5.

[5]. Ary, D., Putranto, (2013). Developers of Healthy Simple Houses Into Healthy Simple Houses with Environmental Insights in Malang Regency, RUAS Journal, Architecture Department, Faculty of Engineering, Universitas Brawijaya Malang, Vol.11 N0 2.No. 5.

[6]. Bureau Central of Statistics, (2019). City of Manado In Data.

[7]. Dimas, Nugraha, (2011). Residential Environmental Quality Model for Rejuvenation of Urban Settlement Areas, Journal of Social-economy of Public Works, Social and Economic Research and Development Center for Settlement Sector Yogyakarta, Vol. 3 No. 3.

[8]. Mahyu Danil, (2010). Influence of Income To Consumption Level On Government Employees Civil the Bireuen Regency Regent's Office, Journal of Economics, Almuslim Bireuen University, Aceh, Vol. IV No. 7: 9.

[9]. Mashudi, et al., (2017), Introduction to Economic Theory, Yogyakarta : Gosyen Publishing, Cet. 1., p. 3 and 9. 
[10]. Regulation of the Minister of State of the Republic of Indonesia Public Housing Number. 22 of 2008 concerning Service Standards.

[11]. Manado City Regional Regulation Number 01 of 2014 Concerning City Manado Spatial Planning.

[12]. Sadono, Sukirno, (2006). Economic Development and Economic Growth, Ed.1. Jakarta : PT Raja Grafindo Persada

[13]. Sadono Sukirno, 2006. Introduction to Microeconomics, Jakarta, PT Raja Grafindo Persada.

[14]. Sangadji, et al., (2010). Research Methodology Practical Approach In Research, Ed.I. Yogyakarta : CV. Andi.

[15]. Soekartawi, (2012). Production Factors-factors, Jakarta : Salemba Empat.

[16]. Soemarno, (2009). Environmental Engineering Management Study Materials, Cet. 1 Malang : PPs Universitas Brawijaya,

[17]. Soemarso S. R., (2009). Accounting An Introduction someth. Issue Five. Jakarta : Salemba Empat.

[18]. Sugiyono, 2017. Statistics For Research, Cet.I. Bandung : Cv. ALFABETA, Number 1.

[19]. Sugiyono 2017. Quantitative, Qualitative, Combination, $\mathrm{R} \& \mathrm{R}$ and Evaluation Research Research Methods, Cet.I. Bandung : Cv. ALFABETA, Number 1.

[20]. Supangat, A., (2010). Statistics In Descriptive And Nonparametric Descriptive Studies, Cet. 3. Jakarta : Kencana,

[21]. Law of the Republic of Indonesia Number: 01 of 2011. concerning Housing and Settlement Areas.

[22]. Urip, Santoso, (2013).Agrarian Law of Comprehensive of Study, Jakarta : Kencana Prenadamedia Group.

[23]. Widyaningsih, 2006. Some Thoughts About Housing, Bandung : Tarsit.

[24]. Yeri, Sutopo, (2017). Inferential Statistics, Yogyakarta : CV. Andi Offet, Issue 1. 